12. 16-24. URL: http://nbuv.gov.ua/UJRN/NiO_2018_11-12_5 [in Ukrainian].

Potashnik, M. (1988). Pedagogicheskoe tvorchestvo: problemy razvitija I opyt: posobie dlja uchitelja [Pedagogical creativity: development problems and experience: a guide for the teacher]. Kiev, 187 [in Russian].

Romenets', V.A. (2001) Psykholohiya tvorchosti [Psychology of creativity]: navch. posibnyk: 2-he vyd., dop. Kyiv: Lybid'. 288 [in Ukrainian].

Ruzhieiro, V.R. (2006). Myshlenie: pjatnadcat' urokov dlja nachinajushhih avtorov [Thinking: Fifteen Lessons for Beginning Writers]. Moscow: Flinta: Nauka, 440 [in Russian].

Barbot, B., \& Heuser, B. (2017). Creativity and identity formation in adolescence: A developmental perspective. In M. Karwowski \& J.C. Kaufman (Eds.). The creative self: Effect of beliefs, self-efficacy, mindset, and identity. 87-98. Elsevier Academic Press. URL: https://doi.org/10.1016/B978-0-12-8097908.00005-4 [in English].

Gajda, A., Karwowski, M. \& Beghetto, R. (2017). Creativity and academic achievement: A meta-analysis. Journal of Educational Psychology, 109/2, 269-299. DOI: http://dx.doi.org/10.1037/edu0000133 [in English].

Kaufman, S. et al. (2016). Openness to experience and intellect differentially predict creative achievement in the Arts and Sciences. Journal of Personality, 84/2, 248-258. DOI: http://dx.doi.org/10.1111/jopy.12156 [in English].

УДК 37.013.83(005.336.2):37.091.12.011.3-051(-027.561)

DOI: https://doi.org/10.35387/od.1(19).2021.72-81

Калюжна Тетяна Григорівна кандидат фрілософрських наук, старший науковий співробітник, провідний науковий співробітник відділу андрагогіки Інституту педагогічної освіти $i$ освіти дорослих імені Івана Зязюна НАПН України
Kaluzhna Tatiana - Candidate of Philosophy, Senior Researcher, Leading Researcher of the Andragogy Department of Ivan Ziaziun Institute of Pedagogical and Adult Education of the NAES of Ukraine

ORCID iD: https://orcid.org/0000-0003-3118-2575

E-mail: tt-dd-kk@ukr.net

\title{
ПРОФЕСІЙНИЙ САМОРОЗВИТОК ЯК ФАКТОР ФОРМУВАННЯ АНДРАГОГІЧНОЇ КОМПЕТЕНТНОСТІ ВИКЛАДАЧА ЗАКЛАДУ ПІСЛЯДИПЛОМНОЇ ПЕДАГОГІЧНОЇ ОСВІТИ
}

\begin{abstract}
Анотація. В оглядовій статті автор розкриває проблему профресійного саморозвитку як складової фоормування андрагогічної компетентності викладача післядипломної педагогічної освіти. Наголошується на важливості особистості викладача, яка є ключовою фрігурою реформ української освіти. Проаналізовано та конкретизовано понятійно-термінологічний апарат дослідження. Розкрито поняття
\end{abstract}


«профресійний розвиток» та вказано, що цей термін трактується науковиями як багатокомпонентний, цілеспрямований, пролонгований $i$ поетапний процес професійного становлення, розвитку та саморозвитку особистості, зорієнтований на набуття нових компетентностей; характеризується неперервністю, системністю, динамізмом, ииклічністю і синергізмом та передбачає перетворення ціннісно-світоглядних орієнтирів, мотиваційної сфери, психологічної структури профресійно-педагогічної діяльності, засвоєння та реалізацію інноваційних профресійних ролей і функцій.

Автор виходить $з$ того, що профресійний саморозвиток викладача післядипломної педагогічної освіти тісно пов'язаний $з$ формуванням у нього андрагогічної компетентності й впливає на процес підготовки та перепідготовки педагогічних працівників, а також $\epsilon$ невід'ємною складовою андрагогічної компетентності.

Акцентовано увагу на тому, що профресійний саморозвиток викладача закладу післядипломної педагогічної освіти має бути усвідомленою потребою в неперервному самовдосконаленні, ставленні до навчання як пріоритету професійної діяльності, а сукупність набутих знань, умінь, навичок, якостей і ціннісних орієнтацій, які необхідні для виконання ролі андрагога - андрагогічна компетентність буде реалізуватись через освітню діяльність, розвиваючи соціально-значимі якості дорослої людини.

Ключові слова: професійний розвиток; саморозвиток; андрагогічна компетентність; викладач; післядипломна педагогічна ocвima.

\section{Kaluzhna Tatiana}

\section{PROFESSIONAL SELF-DEVELOPMENT AS A COMPONENT OF FORMATION OF ANDRAGHIC COMPETENCE OF THE POSTGRADUATE PEDAGOGICAL EDUCATION TEACHER}

Abstract. In the article the author reveals the problem of professional self - development as a component of formation of andragogical competence of the postgraduate pedagogical education teacher. The author emphasizes the importance of the teacher's personality that is a key figure in the Ukrainian education reforms. The conceptual and terminological apparatus of the research is analyzed and concretized in the work. The concept of "professional development» is revealed and it is indicated that this term is interpreted by scientists as a multicomponent, purposeful, prolonged and gradual process of professional formation, development and self-development of a personality focused on acquiring new competencies and that is characterized by continuity, system, dynamism, cyclicality and synergy and provides values and worldviews orientations, motivational sphere, psychological structure of the professional and pedagogical activity, mastering and realization of innovative professional roles and functions. 
The author proceeds from the fact that the professional selfdevelopment of the postgraduate pedagogical education teacher is closely related to the formation of his andragogical competence and influences the process of pedagogical staff training and retraining, and is an integral part of andragogical competence.

Emphasis is placed on the fact that the professional self-development of the postgraduate pedagogical education teacher should be a conscious need for continuous self-improvement, attitude to learning as a priority of professional activity, and the set of acquired knowledge, skills, qualities and values necessary to perform the role of andragogue - andragogical competence will be realized through educational activities and develop socially significant qualities of an adult.

Key words: professional development; self-development; andragogical competence; teacher; postgraduate pedagogical education.

Постановка проблеми, її актуальність. Сучасний стан розвитку системи післядипломної педагогічної освіти в Україні потребує підвищення ролі викладача, оскільки саме андрагогічна компетентність педагогічного персоналу закладу післядипломної педагогічної освіти $\epsilon$ однією із найважливіших якостей, які забезпечують ефективність підготовки та перепідготовки педагогів, формування професійної компетентності фрахівця сучасної української школи. Викладач $є$ ключовою фігурою рефрорм освіти, а тому темпи й характер модернізації системи післядипломної педагогічної освіти залежать насамперед від інтелектуального рівня, професійних та особистісних якостей педагогічного персоналу, зокрема викладача.

Як показує практика, у системі післядипломної педагогічної освіти ефективність підготовки та перепідготовки педагогів залежить від високопрофесійного викладача-андрагога, який добре володіє знаннями теорії, методики та технології роботи з дорослими. Освіта дорослих має специфічний характер, який може бути виражений за допомогою розробки освітніх моделей, заснованих на суб'єкт-суб'єктній взаємодії в процесі навчання. Освітній процес, орієнтований на студентів, будується на вихідних положеннях педагогіки, в навчанні дорослих повинна превалювати андрагогіка.

Сучасні заклади післядипломної педагогічної освіти потребують викладачів, які володіють андрагогічною компетентністю, мають гнучке мислення й здатність працювати нестандартно в сучасному суспільстві в цілому та в педагогічній сфері зокрема. Викладачі, які фрормують унікальний досвід слухачів, мають сприяти активізації внутрішньої активності педагогічних і науково-педагогічних працівників, оскільки сучасні реалії зумовлюють необхідність постійного професійно-особистісного розвитку як слухача, так і власне викладача закладу післядипломної педагогічної освіти. 
Аналіз останніх досліджень і публікацій. Важливість і вагомість саморозвитку педагогічних і науково-педагогічних працівників закладів післядипломної педагогічної освіти у своїх роботах обґрунтовували
Л. Гончаренко,
І. Жорова,
В. Олійник,
В. Примакова,
С. Мельник, М. Романенко, Л. Сущенко, М. Кириченко, О. Худенко. Специфіку навчання дорослих на андрагогічних засадах висвітлено у працях О. Аніщенко, В. Балути, С. Ізбаш, Л. Лук'янової, В. Маслової, М. Скрипник, Т. Сорочан та $\mathrm{iH}$.

Мета статті - уточнити сутність поняття «професійний саморозвиток», розкрити вплив саморозвитку викладача закладу післядипломної педагогічної освіти на фрормування андрагогічної компетентності як важливої складової освітнього процесу закладів післядипломної педагогічної освіти й професійної діяльності педагогічного персоналу.

Виклад основного матеріалу дослідження. У проєкті Стратегії реформування вищої освіти в Україні до 2020 р. в окремому розділі йдеться про необхідність досягнення якісно нового стану рівня академічного персоналу української вищої школи, що $є$ одним з напрямів реформування вищої освіти в Україні. Сучасна освітня парадигма ґрунтується на людиноцентрованому навчанні, мета якого - забезпечення розвитку й саморозвитку особистості людини на основі його індивідуальних особливостей як суб'єкта пізнання. Викладач створює умови для набуття знань у діалозі, у процесі інтелектуальної взаємодії всіх учасників навчального процесу.

Акцентуємо увагу на тому, що на сучасному етапі розвитку педагогічної науки і практики стають затребуваними певні характеристики професійної діяльності викладача, серед яких - уміння працювати в команді, андрагогічні уміння (допомагають виконувати професійні ролі консультанта, експерта, організатора тощо, передбачають володіння діалогічними технологіями і методами навчання). Формування андрагогічної компетентності викладача закладу післядипломної педагогічної освіти $€$ неперервним процесом, спрямованим на розв'язання низки завдань, зокрема, таких: своєчасно реагувати на зміну зовнішнього й внутрішнього оточення, приймати та реалізовувати нестандартні рішення в ситуації конкуренції, адаптуватися до швидких змін умов діяльності, бути готовими до постійного оновлення професійних знань, умінь і навичок.

Нам імпонує визначення Ю. Скиби, сформульоване на основі аналізу тлумачень терміну «професійний розвиток», наведених у працях М. Кириченка, В. Конькової, В. Сидоренко (Кириченко, 2016; Конькова, 2016; Сидоренко, 2016) та інших дослідників, яке охоплює, на нашу думку, цілі та завдання професійного розвитку науково-педагогічного працівника післядипломної педагогічної освіти: професійний розвиток - це багатокомпонентний, цілеспрямований, пролонгований і поетапний процес професійного становлення, розвитку і саморозвитку, зорієнтований на набуття нових компетентностей i характеризується неперервністю, системністю, динамізмом, циклічністю і синергізмом та передбачає 
перетворення ціннісно-світоглядних орієнтирів, мотиваційної сфрери, психологічної структури професійно-педагогічної діяльності, засвоєння та реалізацію інноваційних професійних ролей і функцій (Теоретичні основи і технологія професійного розвитку, 2017, с. 9).

Поняття саморозвиток має низку істотних відмінностей від поняття розвиток. Саморозвиток має в основі творчу суть; інтенсифікує процеси «самозвеличання»; активізує самовплив і взаємодію особистості самої 3 собою; відрізняється мотивованістю, тоді як розвиток характеризується спонтанністю, і в результаті виникають неусвідомлювані зміни якостей особистості (Ільчук, 2016).

Аналіз фрілософських, педагогічних і психологічних праць, присвячених досліджуваному феномену, показує, що саморозвиток може розглядатися (досліджуватися) у різних аспектах, а саме: як мета, засіб, явище, процес, стан, зміна, результат, підсумок тощо. До прикладу, саморозвиток розглядається як: саморух (Ф. Гегель, І. Кант, Г. Сковорода, Й. Фіхте, Ф. Шеллінг), діяльність, внутрішня активність (В. Андрєєв, Г. Балл, М. Боришевський, Г. Костюк, С. Рубінштейн, П. Чамата), потреба (І. Булах, С. Максименко, Е. Помиткін), здатність, характеристика (В. Маралов, Н. Пов'якель), зміна (М. Гайдеггер, Ф. Енгельс, К. Маркс, С. Франк, М. Мамардашвілі, Г. Цукерман), процес (Я. Коменський, Дж. Локк, Й. Песталоцці, Ж.-Ж. Руссо), механізм (3. Карпенко, Т. Титаренко, В. Ямницький), технологія (Ю. Лобейко, Г. Селевко, Т. Тихонова). Зазначимо, що тлумачення саморозвитку як механізму особистіснопрофесійного зростання зустрічається переважно у педагогіці.

Відповідно до Оксфордського тлумачного словника з психології, саморозвиток являє собою зростання Я, рух до емоційної та когнітивної зрілості чи (за моделлю А. Маслоу) - поступальний рух до самоактуалізації. В обох цих визначеннях чітко простежується природно задана спрямованість саморозвитку особистості на шляху до їі максимального вдосконалення.

Дефініцію професійного саморозвитку професор Г. Балл визначає як: «..особливий, самостійний вид внутрішньої активності, що спрямований на усвідомлення людиною самої себе як суб'єкта діяльності та зумовлює продуктивне професійне становлення, професійний розвиток і перетворення «фахівця на професіонала».

Науковець В. Лозовецька, досліджуючи професійний саморозвиток особистості наголошує на тому, що це «...складний соціальнопсихологічний феномен, що зумовлює появу життєво важливих проблем і ситуацій, розв'язання яких потребує відповідної психолого-педагогічної підтримки у формуванні професійних ринкових цінностей щодо ефективної адаптації особистості до нових умов діяльності» (Лозовецька, 2011). 
Погоджуємося з думкою Е. Остапенко про те, що професійний саморозвиток $є$ процесом безперервного, свідомого, цілеспрямованого особистісно-профресійного самовдосконалення особистості, який являє собою внутрішньо та зовнішньо організований свідомий інтеграційний процес самоуправління особистості, що ґрунтується на механізмах самопізнання, самоствердження, самовдосконалення та самоактуалізації (Остапенко, 2015).

Отже, професійний саморозвиток викладача післядипломної педагогічної освіти $€$ особистісно-профресійним, усвідомленим і мотивованим процесом, який тісно пов'язаний 3 формуванням андрагогічної компетентності викладача шляхом неперервної професійної самоосвіти. Професійний саморозвиток викладача закладу післядипломної педагогічної освіти «...здійснюється з допомогою механізмів самопізнання, самоорганізації, самоосвіти, самооцінки, саморегуляції як прагнення до самоактуалізації на основі розвитку професійного мислення, реалізації творчого потенціалу, різноманітних форм дослідницької діяльності та інших способів інтенсифікації цього процесу» (Ільчук, 2016).

За Т. Сорочан, А. Данильєвим (Сорочан \& Данильєв, 2013), «... сам дорослий педагог відіграє провідну роль у формуванні мотивації та визначенні цілей свого навчання. У цьому випадку завдання викладачів, методистів полягає в тому, щоб створити педагогам сприятливі умови для навчання, забезпечити їх необхідними методами та критеріями, які допоможуть з'ясувати свої потреби в навчанні».

Отже, викладач закладу післядипломної педагогічної освіти мотивуючи слухачів-педагогів до навчання, створюючи їм сприятливі умови підвищує свою андрагогічну компетенцію, застосовуючи у професійній діяльності відповідні андрагогічні принципи, які виокремлює у своєму дослідженні Л. Лук'янова: єдності трьох середовищ (навчальне, професійне, соціальне); відкритості освітнього простору; синтез трьох підходів до освіти (андрагогічний, особистісно орієнтований, контекстний); діяльності; постійної підтримки; професійної мотивації; елективності навчання; розвитку освітніх потреб; контекстності навчання; ресрлективності (Лук'янова, 2015, с. 33).

Одним із завдань викладача закладу післядипломної педагогічної освіти $€$ удосконалення роботи в між курсовий період за темою самоосвітньої діяльності шляхом самоосвіти, саморозвитку та пошуку шляхів самореалізації особистості вчителя. Педагогічні працівники повинні бути здатні до постійного самовдосконалення, орієнтованого на відповідність динаміці дійсності. «Якщо людина не знає, до якої мети вона рухається, для неї жоден вітер не буде попутним», - сказав Сенека. Цей вислів влучно розкриває зміст самовдосконалення педагогічного персоналу закладів післядипломної педагогічної освіти. 
Завдяки моніторингу особистої педагогічної діяльності викладача відбувається накопичення інфрормації про рівень самоосвіти викладача. Таким чином, у кожного викладача з'являється можливість прогнозувати та моделювати особистий розвиток, забезпечуючи безперервне професійне зростання. Самоосвіта викладача $€$ основною фрормою підвищення професійної педагогічної компетентності, яка складається з удосконалення знань та узагальнення педагогічного досвіду шляхом цілеспрямованої самоосвітньої роботи (Подолець, 2019).

Відмінною рисою саморозвитку викладача закладу післядипломної педагогічної освіти $€$ те, що результатом його роботи виступає не лише самовдосконалення в особистому та професійному плані, а й підвищення ефективної взаємодії зі слухачами, що і $€$ результатом формування андрагогічної компетентності викладача закладу післядипломної педагогічної освіти. Комунікативна роль викладача трансформується від транслятора готових знань до викладача-андрагога 3 ролями фрасилітатора, модератора, тьютора, коуча.

Важливою професійною якістю викладача закладу післядипломної педагогічної освіти $є$ упевненість у собі, що забезпечує оптимальну мобілізованість і стабільність поведінки. Зазначимо, що у період карантину мобільність викладача закладу післядипломної педагогічної освіти $\epsilon$ необхідним показником андрагогічної компетентності в умовах ускладнення ситуації навчання, необхідності аналізу конкретних андрагогічних ситуацій.

Як свідчить дослідження В. Приходька, серед основних характеристик андрагогічної компетентності викладача закладу післядипломної педагогічної освіти доцільно виокремити такі: прагнення до самовизначення; автономність особистості як прояв високого рівня самореалізації; прагнення знайти форми контролю, які схвалює й цінує категорія дорослих учнів; вирішення проблем, пов'язаних із мовною та комунікаційною культурою викладачів; мотивація до використання ефективних технологій навчання дорослих (Приходько, 2012).

Показниками андрагогічної позиції та освітньої стратегії для викладача закладу післядипломної педагогічної освіти є: виявлення ефекту розвиваючого змісту за рахунок внесення в освітній простір досвіду слухачів; задоволеність результатами навчання на індивідуальному й груповому рівнях; бажання слухачів продовжити взаємні контакти після закінчення навчання.

Висновки і перспективи подальших досліджень. Отже, дослідження формування андрагогічної компетентності викладача слід розглядати як складний соціально-психологічний феномен, що зумовлює появу життєво-важливих проблем і ситуацій, розв'язання яких потребує відповідної психолого-педагогічної підтримки у формуванні професійних цінностей щодо ефективної адаптації особистості до нових умов діяльності. Водночас професійний саморозвиток викладача закладу післядипломної педагогічної освіти має бути усвідомленою потребою в неперервному самовдосконаленні, ставленні до навчання як пріоритету 
професійної діяльності, а сукупність набутих знань, умінь, навичок, якостей і ціннісних орієнтацій сприятимуть удосконаленню освітньої діяльності, спрямованої на розвиток соціально-значимих якостей дорослої людини. Новий етап модернізації післядипломної педагогічної освіти щодо формування андрагогічної компетентності сучасного викладача потребує оновлення цілей та потреб з обов'язковим осучасненням змісту, форм і методів навчання, організацією відповідної навчальної діяльності щодо розвитку творчої, креативної особистості педагога задля успішного виконання професійних завдань.

Перспективним напрямом подальших досліджень вважаємо проблему розвитку андрагогічної компетентності викладача закладу післядипломної педагогічної освіти в умовах неформального навчання.

\section{Список використаних джерел}

Ільчук, В. (2016). Педагогічні умови професійного саморозвитку викладачів фрахових дисциплін у вищих аграрних навчальних закладах: дис. ... канд. пед. наук: 13.00.04. Вінниця.

Кириченко, М. (2016). Інноваційні підходи до професійного розвитку педагогічних, науково-педагогічних працівників та керівних кадрів освіти у відкритому суспільстві. Профресійний розвиток та управління людськими ресурсами в системі післядипломної педагогічної освіти в контексті трансформації освіти України: зб. матеріалів Всеукраїнської наук.-практ. конф., Київ, 28 жовтня 2016 p. 16-30. URL: https://cutt.ly/9b0JVrK

Конькова, В.В. (2016). Самоменеджмент керівника навчального закладу. Профресійний розвиток та управління людськими ресурсами в системі післядипломної педагогічної освіти в контексті трансформації освіти України: зб. матеріалів Всеукраїнської наук.-практ. конф., Київ, 28 жовтня 2016 р. 372-375. URL: https://cutt.ly/9b0JVrK

Лозовецька, В. (2011). Концептуальні засади професійного саморозвитку сучасної особистості. Науковий вісник Інституту профресійнотехнічної освіти НАПН України. Профресійна педагогіка, 1. 33-39. URL: http://nbuv.gov.ua/UJRN/Nvipto_2011_1_7

Лук'янова, Л. (2015). Акмеологічний ресурс андрагогічної моделі навчання. Проблеми освіти, 84, 31-36. URL: https://cutt.ly/YbOKjHj

Остапенко, Е. (2015). Формування готовності майбутніх економістів до професійного саморозвитку: автореф. дис. ... канд. пед. наук: 13.00.04. Київ.

Подолець, К. (2019). Загальні теоретичні заходи щодо самофрормування психолого-педагогічної проблеми «Шлях до досконалості». URL: https://cutt.ly/6b0Kv9U

Приходько, В. (2012). Системні аспекти моніторингу професійних якостей педагога-андрагога в системі післядипломної освіти. Особистість у єдиному освітньому просторі: зб. наукових тез III Міжнародного Форуму 26-29 квітня 2012 р. 1 (7). URL: 
https://virtkafedra.ucoz.ua/el_gurnal/pages/vyp7/konf3/Prihodko.pdf

Сидоренко, В. (2016). Педагогічне дорадництво як інноваційний напрям акмепрофресіогенезу фрахівців у системі ППО. Профресійний розвиток та управління людськими ресурсами в системі післядипломної педагогічної освіти в контексті трансформації освіти України: зб. матеріалів Всеукраїнської наук.-практ. конф. Київ, 28 жовтня 2016 р. 145-148. URL: https://cutt.ly/vbOKRCj

Сорочан, Т. \& Данильєв, А. (2013). Профресійний розвиток керівників $і$ педагогічних працівників загальноосвітніх навчальних закладів у післядипломній педагогічній освіті регіонального рівня (за мат. Луганського обласного інституту післядипломної педагогічної освіти), 524. URL: https://lib.iitta.gov.ua/26581/

Теоретичні основи і технологія професійного розвитку науковопедагогічних працівників університетів в умовах інтеграції вищої освіти і науки: препринт (аналітичні матеріали) (2017). Авт. кол.: О. Бульвінська, Н. Дівінська, Н. Дяченко, О. Жабенко, І. Линьова, Ю. Скиба, Г. Чорнойван, О. Ярошенко; за ред. О. Ярошенко. К.: IBO НАПН України. У 2-х ч. Ч. 1. URL: https://cutt.ly/ebOKSS0

\section{References (translated and transliterated)}

Ilchuk, V. (2016). Pedahohichni umovy profesiinoho samorozvytku vykladachiv fakhovykh dystsyplin u vyshchykh ahrarnykh navchalnykh zakladakh [Pedagogical conditions of professional self-development of teachers of professional disciplines in higher agrarian educational institutions]. Candidate's theses: 13.00.04. Vinnytsia, 254 [in Ukrainian].

Kyrychenko, M. (2016). Innovatsiini pidkhody do profesiinoho rozvytku pedahohichnykh, naukovo-pedahohichnykh pratsivnykiv ta kerivnykh kadriv osvity u vidkrytomu suspilstvi. Profesiinyi rozvytok ta upravlinnia liudskymy resursamy $v$ systemi pisliadyplomnoi pedahohichnoi osvity $v$ konteksti transformatsii osvity Ukrainy [Innovative approaches to the professional development of pedagogical, scientific and pedagogical workers and managers of education in an open society. Professional development and human resources management in the system of postgraduate pedagogical education in the context of transformation of education in Ukraine]: $\mathrm{zb}$. materialiv Vseukrainskoi nauk.-prakt. konf., Kyiv, 28 zhovtnia 2016 r., 1630. URL: https://cutt.ly/9b0JVrK [in Ukrainian].

Konkova, V. (2016). Samomenedzhment kerivnyka navchalnoho zakladu. Profesiinyi rozvytok ta upravlinnia liudskymy resursamy $v$ systemi pisliadyplomnoi pedahohichnoi osvity $v$ konteksti transformatsii osvity Ukrainy [Selfmanagement of the head of the educational institution. Professional development and human resources management in the system of postgraduate pedagogical education in the context of transformation of education in Ukraine]: zb. materialiv Vseukrainskoi nauk.-prakt. konf., Kyiv, 28 zhovtnia 2016 r., 372-375. URL: https://cutt.ly/9b0JVrK [in Ukrainian].

Lozovetska, V. (2011). Kontseptualni zasady profesiinoho samorozvytku suchasnoi osobystosti [Conceptual principles of professional self-development of modern personality]. Naukovyi visnyk Instytutu profesiino-tekhnichnoi 
osvity NAPN Ukrainy. Profesiina pedahohika. - Scientific Bulletin of the Institute of Vocational Education of the National Academy of Pedagogical Sciences of Ukraine. Professional pedagogy, 1, 33-39. URL: http://nbuv.gov.ua/UJRN/Nvipto_2011_1_7 [in Ukrainian].

Lukianova, L. (2015). Akmeolohichnyi resurs andrahohichnoi modeli navchannia [Acmeological resource of andragogical model of education]. Problemy osvity - Problems of education, 84, 31-36. URL: https://cutt.ly/YbOKjHj [in Ukrainian].

Ostapenko, E. (2015). Formuvannia hotovnosti maibutnikh ekonomistiv do profesiinoho samorozvytku [Formation of readiness of future economists for professional self-development]. Extended abstract of Candidate's theses. Kyiv [in Ukrainian].

Podolets, K.V. (2019). Zahalni teoretychni zakhody shchodo samoformuvannia psykholoho-pedahohichnoi problemy "Shliakh do doskonalosti» [General theoretical measures for self-formation of psychological and pedagogical problems «Path to perfection»]. URL: https://cutt.ly/6b0Kv9U [in Ukrainian].

Prykhodko, V. (2012). Systemni aspekty monitorynhu profesiinykh yakostei pedahoha-andrahoha $\mathrm{v}$ systemi pisliadyplomnoi osvity. Osobystist $\mathrm{u}$ yedynomu osvitnomu prostori [Systemic aspects of monitoring the professional qualities of an andragogue teacher in the system of postgraduate education. Personality in a single educational space]: $\mathrm{zb}$. naukovykh tez III Mizhnarodnoho Forumu 26 - 29 kvitnia 2012 r., 1 (7). URL: https://virtkafedra.ucoz.ua/el_gurnal/pages/vyp7/konf3/Prihodko.pdf [in Ukrainian].

Sydorenko, V. (2016). Pedahohichne doradnytstvo yak innovatsiinyi napriam akmeprofesiohenezu fakhivtsiv u systemi PPO. Profesiinyi rozvytok ta upravlinnia liudskymy resursamy $v$ systemi pisliadyplomnoi pedahohichnoi osvity $v$ konteksti transformatsii osvity Ukrainy [Pedagogical counseling as an innovative direction of acmeprofessiogenesis of specialists in the air defense system. Professional development and management of human resources in the system of postgraduate pedagogical education in the context of transformation of education in Ukraine]: $\mathrm{zb}$. materialiv Vseukrainskoi nauk.-prakt. konf., Kyiv, 28 zhovtnia 2016 r., 145-148. URL: https://cutt.ly/vbOKRCj [in Ukrainian].

Sorochan, T., Danyliev, A. (2013). Profesiinyi rozvytok kerivnykiv i pedahohichnykh pratsivnykiv zahalnoosvitnikh navchalnykh zakladiv u pisliadyplomnii pedahohichnii osviti rehionalnoho rivnia [Professional development of heads and pedagogical workers of general educational institutions in postgraduate pedagogical education of regional level]: (za mat. Luhanskoho oblasnoho instytutu pisliadyplomnoi pedahohichnoi osvity). URL: https://lib.iitta.gov.ua/26581 [in Ukrainian].

Teoretychni osnovy i tekhnolohiia profesiinoho rozvytku naukovo-pedahohichnykh pratsivnykiv universytetiv $v$ umovakh intehratsii vyshchoi osvity i nauky (2017). [Theoretical bases and technology of professional development of scientific and pedagogical workers of universities in the conditions of integration of higher education and science]. Preprynt (analitychni materialy): U 2-kh ch. Ch. 1. K. 131. URL: https://cutt.ly/ebOKSS0 [in Ukrainian]. 